\title{
UPAYA MENINGKATKAN HASIL BELAJARIPS MELALUI PENERAPAN MODEL PEMBELAJARAN NUMBERED HEAD TOGETHER (NHT) SISWA KELAS IX.5 SMP NEGERI 2 METRO TAHUN PELAJARAN 2012/2013
}

\author{
Nurmala \\ SMP NEGERI 2 METRO \\ Ibunurmala234@gmail.com
}

\begin{abstract}
Abstrak
Di SMP Negeri 2 Metro, guru dalam proses pembelajaran kurang memodivikasi metode pembelajaran IPS Terpadu. Hal ini terjadi karena pola pikir belajar diartikan sebagai perolehan pengetahuan, dan mengajar adalah memindahkan pengetahuan kepada siswa, disamping itu pembelajaran ditekankan pada hasil, bukan pada proses. Akibatnya proses pembelajaran di kelas menjadi monoton karena guru hanya menungunan metode konvensional dan aktivitas siswa di kelas hanya mencatat lebih dominan dengan menghafal. Pembelajaran IPS Terpadu di kelas ditekankan pada keterkaitan antara konsep-konsep IPS Terpadu dengan pengalaman anak sehari-hari. Selain itu, perlu menerapkan kembali konsep IPS Terpadu yang telah dimiliki anak pada kehidupan sehari-hari atau pada bidang lain sangat penting dilakukan. Untuk memudahkan pemahaman siswa tentang hal tersebut, maka salah satu upaya yang dapat dilakukan adalah dengan menerapkan model pembelajaran Numbered Heads Together. Penelitian ini dilakukan di SMP Negeri 2 Metro.Penelitian direncanakan selama 3 (tiga) bulan dimulai pada bulan September sampai dengan bulan November 2013. Subjek pada penelitian tindakan kelas ini adalah siswa Kelas IX.5 dengan jumlah siswa 28 orang, yang terdiri dari 18 orang laki-laki dan 10 orang perempuan. Penelitian dilaksanakan pada saat mata pelajaran IPS Terpadu berlangsung dengan Standar Kompetensi "Memahami usaha persiapan kemerdekaan,". Dipilihnya kelas ini yang menjadi subjek dalam penelitian karena kelas ini termasuk yang menjadi tugas penulissebagai guru IPS Terpadu dan dari segi prestasi cukup refresentatif dijadikan subjek dalam penelitian. Pada siklus I Pada siklus-1 ini terdapat 4 siswa yang memperoleh hasil belajar diatas penguasaan minimal, 18 siswa memperoleh hasil belajar sesuai dengan batas minimal, dan 6 siswa belum sesuai dengan yang diharapkan. Hasil belajar siswa pada siklus - 2 terdapat 15 siswa yang memperoleh hasil belajar diatas penguasaan minimal dan 13 siswa yang memperoleh hasil belajar sesuai dengan yang diharapkan. Hasil belajar siswa pada pembelajaran IPS Terpadu melalui Model pembelajaran Numbered Head Together sudah ada peningkatan.
\end{abstract}

Kata kunci: Hasil Belajar,Model pembelajaran Numbered Head Together (NHT)

\section{PENDAHULUAN}

Salah satu upaya untuk meningkatkan keberhasilan belajar siswa, yaitu dengan menggunakan pembelajaran aktif di mana siswa melakukan sebagian besar pekerjaan yang harus dilakukan. Siswa menggunakan 
otak untuk melakukan pekerjaannya, mengeluarkan gagasan, memecahkan masalah dan dapat menerapkan apa yang mereka pelajari. Belajar aktif merupakan langkah cepat, menyenangkan, mendukung dan menarik hati dalam belajar untuk mempelajari sesuatu dengan baik. Belajar aktif membantu untuk mendengar, melihat, mengajukan pertanyaan tentang pelajaran tertentu dan mendiskusikannya dengan yang lain.

Di SMP Negeri 2 Metro, selama ini guru kurang kreatif menerapkan inovasi pembelajaran IPS Terpadu. Hal ini terjadi karena pola pikir belajar diartikan sebagai perolehan pengetahuan, dan mengajar adalah memindahkan pengetahuan kepada siswa, disamping itu pembelajaran ditekankan pada hasil, bukan pada proses. Akibatnya proses pembelajaran di kelas menjadi monoton karena guru hanya menungunan metode konvensional dan aktivitas siswa di kelas hanya mencatat lebih dominan dengan menghafal.. Pembelajaran IPS Terpadu di kelas ditekankan pada keterkaitan antara konsepkonsep IPS Terpadu dengan pengalaman anak sehari-hari. Selain itu, perlu menerapkan kembali konsep IPS Terpadu yang telah dimiliki anak pada kehidupan sehari-hari atau pada bidang lain sangat penting dilakukan.
Hasil evaluasi yang baik dan memenuhi standar KKM adalah salah satu indikator tercapainya tujuan pembelajaran di kelas. Untuk mencapai hal tersebut banyak yang harus dilakukan seorang guru misalnya saja menggunakan berbagai model pembelajaran yang disenagi oleh siswa, dalam rangka memudahkan pemahaman siswa terhadap materi-materi pelajaran khususnya mata pelajaran IPS Terpadu. Di Kelas IX.5, SMP Negeri 2 Metro, selain masalah hasil belajar yang masih rendah, khususnya pada kompetensi dasar Menjelaskan Proses persiapan kemerdekaan Indonesia, terdapat pula kendala dalam proses pembelajaran.

Untuk memudahkan pemahaman siswa tentang hal tersebut, maka salah satu upaya yang dapat dilakukan adalah dengan menerapkan model pembelajaran Numbered Heads Together.

Ada beberapa manfaat pada model pembelajaran kooperatif tipe NHT terhadap siswa yang hasil belajar rendah antara lain adalah : 1) Rasa harga diri menjadi lebih tinggi; 2) Memperbaiki kehadiran; 3) Penerimaan terhadap individu menjadi lebih besar; 4) Perilaku mengganggu menjadi lebih kecil; 5) Konflik antara pribadi berkurang; 6) Pemahaman yang lebih mendalam; 7) Meningkatkan kebaikan budi, kepekaan 
dan toleransi; 8) Hasil belajar lebih tinggi

(Ibrahim, 2000).

Berdasarkan uraian diatas maka Penelitian Tindakan Kelas (PTK) ini, dirancang untuk mengkaji penerapan pembelajaran model "Numbered Head Together" dalam meningkatkan hasil belajar IPS Terpadu, sehingga akan memungkinkan untuk dapat mengaktifkan siswa sehingga dapat meningkatkan hasil belajar siswa.

\section{KAJAIN PUSTAKAN}

\section{Model Pembelajaran Kooperatif}

\section{Tipe Numbered Heads Together}

Model Pembelajaran Kooperatif Tipe Numbered Head Together

Numbered Head Together (NHT) merupakan suatu pendekatan yang dikembangkan oleh Kagan, (1993) untuk melibatkan banyak siswa dalam memperoleh materi yang tercakup dalam suatu pelajaran dan mengecek pemahaman mereka terhadap isi pelajaran.

Ibrahim, (2000:25). Model NHT adalah bagian dari model pembelajaran kooperatif struktural, yang menekankan pada struktur-struktur khusus yang dirancang untuk mempengaruhi pola interaksi siswa.

Pendapat seperti di atas juga di dukung oleh para ahli yang lain seperti
Muslimin, (2000:65) yang mengemukakan bahwa:

"Numbered Head Together adalah salah satu tipe dari pembelajaran kooperatif dengan sintaks: pengarahan, buat kelompok heterogen dan tiap siswa memiliki nomor tertentu, berikan persoalan materi bahan ajar (untuk tiap kelompok sama tetapi untuk tiap siswa tidak sama sesuai dengan nomor siswa, tiap siswa dengan nomor yang sama mendapat tugas yang sama) kemudian bekerja dalam kelompok, presentasi kelompok dengan nomor siswa yang sama sesuai tugas masing-masing sehingga terjadi diskusi kelas, kuis individual dan buat skor perkembangan tiap siswa, umumkan hasil kuis dan beri reward"

Ibrahim (2000:25). mengemukakan tiga tujuan yang hendak dicapai dalam pembelajaran kooperatif dengan tipe NHT yaitu :

1. Hasil belajar akademik stuktural bertujuan untuk meningkatkan kinerja siswa dalam tugas-tugas akademik.

2. Pengakuan adanya keragaman bertujuan agar siswa dapat menerima teman-temannya yang mempunyai berbagai latar belakang.

3. Pengembangan keterampilan sosial bertujuan untuk mengembangkan keterampilan sosial siswa. Keterampilan yang dimaksud antara lain berbagi tugas, aktif bertanya, menghargai pendapat orang lain, mau menjelaskan ide atau pendapat, 
bekerja dalam kelompok dan sebagainya

Ada beberapa manfaat pada model pembelajaran kooperatif tipe NHT terhadap siswa yang hasil belajar rendah yang dikemukakan oleh Ibrahim (2000: 18), antara lain adalah :

a. Rasa harga diri menjadi lebih tinggi

b. Memperbaiki kehadiran

c. Penerimaan terhadap individu menjadi lebih besar

d. Perilaku mengganggu menjadi lebih kecil

e. Konflik antara pribadi berkurang

f. Pemahaman yang lebih mendalam

g. Meningkatkan kebaikan budi, kepekaan dan toleransi

h. Hasil belajar lebih tinggi

\section{Hasil Belajar}

Hasil belajar adalah segala kemampuan yang dapat dicapai siswa melalui proses belajar yang berupa pemahaman dan penerapan pengetahuan dan keterampilan yang berguna bagi siswa dalam kehidupannya sehari-hari serta sikap dan cara berpikir kritis dan kreatif dalam rangka mewujudkan manusia yang berkualitas, bertanggung jawab bagi diri sendir, masyarakat, bangsa dan negara serta bertanggung jawab kepada Tuhan Yang Maha Esa.
Menurut Suprijono

$(2013: 5)$

mengemukakan bahwa "Hasil belajar adalah pola-pola perbuatan, nilai-nilai, pengertian-pengertian, sikap-sikap, apresiasi dan keterampilan". Sedang menurut Slameto (2003:2) menjelaskan bahwa "hasil belajar adalah suatu proses yang dilaksanakan seseorang untuk memperoleh suatu perubahan tingkah laku yang baru yang secara keseluruhan sebagai hasil pengalaman sendiri, sebagai hail perubahan dalam intruksi dengan lingkungan".

Hasil belajar ada beberapa faktor yang mempengaruhinya, hal ini sesuai dengan pendapat yang dikemukakan oleh Slameto (2003:54) yang menyebutkan bahwa faktor-faktor yang mempengaruhi hasil belajar yaitu:

1. Faktor internal (faktor dari dalam siswa) meliputi:

a) Faktor jasmani yang mencakup kesehatan dan cacat tubuh.

b) Faktor psikologi yang mencakup dari intelegensi, perhatian, minat, bakat, motif, kematangan dan kesiapan.

c) Faktor kelelahan

2. Faktor eksternal (faktor dari luar siswa) meliputi:

a) Faktor keluarga yang mencakup cara orang tua mendidik, relasi 
antara anggota keluarga, suasana rumah, keadaan ekonomi keluarga, dan latar belakang kebudayaan.

b) Faktor sekolah yang mencakup dari metode mengajar guru, kurikulum, relasi guru dengan siswa, relasi siswa dengan siswa, disiplin sekolah, alat dan media pelajaran, waktu sekolah, standar belajar di atas ukuran, dan tugas rumah.

c) Faktor masyarakat yang mencakup kegiatan siswa dalam masyarakat media massa, taman bergaul, dan bentuk masyarakat.

Berdasarkan pendapat di atas dapat disimpulkan bahwa hasil belajar merupakan perubahan tingkah laku yang terjadi pada siswa setelah mengikuti pelajar, perubahan tersebut terjadi pada kemampuan kognitif, afektif, dan psikomotor.

\section{METODE PENELITIAN}

Metode dalam penelitian ini adalah meto depenelitian tindakan kelas (Class Action Research). Apabila sudah diketahui keberhasilan atau hambatan dalam tindakan yang dilaksanakan padasiklus pertama, peneliti mengidentifikasi permasalahan baru untuk menentukan rancangan siklus berikutnya. Kegiatan pada siklus kedua, dapat berupa kegiatan yang sama dengan sebelumnya bila ditujukan untuk mengulangi keberhasilan, untuk meyakinkan, atau untuk menguatkan hasil. Pada umumnya kegiatan yang dilakukan dalam siklus kedua mempunyai berbagai tambahan perbaikan dari tindakan sebelumnya yang ditunjukan untuk mengatasi berbagai hambatan/ kesulitan yang ditemukan dalam siklus sebelumnya.

Menurut Adlan, (2011:17) Rencana Tindakan. Pada bagian ini digambarkan rencana tindakan untuk meningkatkan pembelajaran, seperti:

1) Perencanaan, yaitu persiapan yang dilakukan sehubungan dengan PTK yang diprakarsai seperti penetapan tindakan, pelaksanaan tes diagnostik untuk menspesifikasi masalah, pembuatan skenario pembelajaran, pengadaan alat-alat dalam rangka implementasi PTK, dan lain-lain yang terkait dengan pelaksanaan tindakan perbaikan yang ditetapkan. Disamping itu juga diuraikan alternatif-alternatif solusi yang akan dicobakan dalam rangka perbaikan masalah

2) Implementasi Tindakan, yaitu deskripsi tindakan yang akan dilakukan. Skenario kerja tindakan perbaikan dan prosedur tindakan yang akan diterapkan.

3) Observasi dan Interpretasi, yaitu uraian tentang prosedur perekaman dan penafsiran data mengenai proses 
dan produk dari implementasi tindakan perbaikan yang dirancang.

4) Analisis dan Refleksi, yaitu uraian tentang prosedur analisis terhadap hasil pemantauan dan refleksi berkenaan dengan proses dan dampak tindakan perbaikan yang akan digelar, personel yang akan dilibatkan serta kriteria dan rencana bagi tindakan berikutnya.

Prosedur pelaksanaan PTK yang meliputi penetapan fokus permasalahan, perencanaantindakan, pelaksanaan tindakan yang diikuti dengan kegiatan

Untuk lebih jelasnya, rangkaian kegiatan dari setiap siklus dapat dilihat pada gambar berikut:

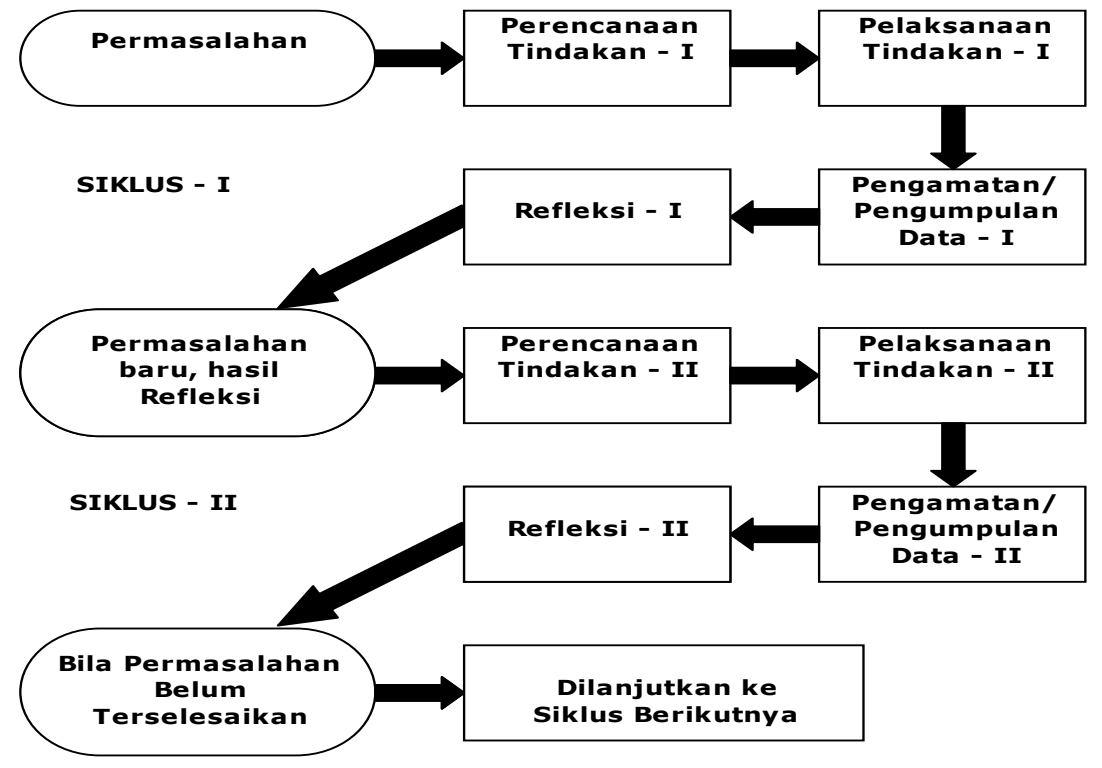

Gambar 3. 1. Siklus Kegiatan PTK (Adlan (2011:18)

Setelah permasalahan ditetapkan, pelaksanaan PTK dimulai dengan siklus pertama yang terdiri atas empat kegiatan. observasi, interpretasi, dan analisis, serta refleksi. Apabila diperlukan, pada tahap selanjutnya disusun rencana tindak lanjut. Upaya tersebut dilakukan secara berdaur membentuk suatu siklus. Langkah-langkah pokok yang ditempuh pada siklus pertama dan siklus-siklus berikutnya adalah:
a) Penetapan fokus permasalahan
b) Perencanaan tindakan
c) Pelaksanaan tindakan
d) Pengumpulan data
e) Refleksi
f) Perencanaan tindak lanjut. 
kemudian mengidentifikasi permasalahan baru untuk menentukan rancangan siklus berikutnya. Kegiatan pada siklus kedua, dapat berupa kegiatan yang sama dengan sebelumnya bila ditujukan untuk mengulangi keberhasilan, untuk meyakinkan, atau untuk menguatkan hasil. Pada umumnya kegiatan yang dilakukan dalam siklus kedua mempunyai berbagai tambahan perbaikan dari tindakan sebelumnya yang ditunjukan untuk mengatasi berbagai hambatan/ kesulitan yang ditemukan dalam siklus sebelumnya.

Aspek yang diamati dalam setiap siklusnya adalah kegiatan atau aktivitas siswa saat mata pelajaran IPS Terpadu dengan pendekatan model pembelajaranNumbered Head Together untuk melihat perubahan tingkah laku siswa, untuk mengetahui tingkat kemajuan belajarnya yang akan berpengaruh terhadap hasil belajar dengan alat pengumpul data yang sudah disebutkan diatas.

Data yang diambil adalah data kuantitatif dari hasil tes, presensi, nilai tugas seta data kualitatif yang menggambarkan keaktifan siswa, antusias siswa, partisipasi dan kerjasama dalam diskusi, kemampuan atau keberanian siswa dalam melaporkan hasil.

Bila $70 \%$ siswa telah berhasil melampaui KKM IPS Terpadu yaitu 70, melalui model pembelajaran Numbered Head Together, maka tindakan tersebut diasumsikan sudah berhasil. Kriteria keberhasilan penelitian ini dari sisi proses dan hasil. Sisi proses yaitu dengan berhasilnya siswa memecahkan masalah melalui model pembelajaran Numbered Head Together dengan mengadakan diskusi kelompok belajar, dimana para siswa dilatih untuk berani mengeluarkan pendapat dan/atau berbeda pendapat tentang masalah Memahami usaha persiapan kemerdekaan.

\section{PEMBAHASAN HASIL PENELITIAN}

\section{Hasil yang dicapai pada siklus-1}

Berdasarkan analisis data dicapai pada siklus- I meliputi: 1) Aktivitas belajar siswa 2) hasil belajar siswa , c) tanggapan siswa, d) tanggapan guru kelas, pada pembelajaran melalui Model pembelajaran Numbered Head Toget herdapat meningkatkan hasil belajar IPS Terpadu pada siswa Kelas IX.5. Pada Kompetensi Dasar Memahami usaha persiapan kemerdekaan.

Aktivitas belajar siswa pada pembelajaran siswa Melalui model pembelajaran Numbered Head Together, berada pada kualitas tinggi, rinciannya sebagai berikut:

1) Aktivitas belajar siswa pada tahap pendahuluan, adalah tinggi. 
2) Aktivitas belajar siswa pada tahap memahami materi menyusun informasi, rumus hipotesis, pengujian hipotesis, dan membuat kesimpulan adalah tinggi.

Pada siklus- I sebagian besar siswa telah mencapai hasil belajar sesuai/diatas batas penguasaan materi minimal yang ditetapkan. Batas penguasaan materi minimal yang ditetapkan dalam penelitian ini adalah 70.Pada siklus-1 initer dapat 4 siswa yang memperoleh hasil belajar diatas penguasaan minimal, 18 siswa memperoleh hasil belajar sesuai dengan batas minimal, dan 6 siswa belum sesuai dengan yang diharapkan.

Hasil wawancara dengan siswa pada tindakan siklus-I ini sermua siswa memberikan tanggapan positif terhadap pembelajaran siswa Melalui Model pembelajaran Numbered Head Together, padamata pelajaran IPS Terpadu.

Berdasarkan hasil wawancara dengan guru Kelas IX.5, member tanggapan positif terhadap pembelajaran siswa melalui model pembelajaran Numbered Head Together, pada mata pelajaran IPS Terpadu.

\section{Hasil yang dicapai pada siklus-2}

Dari hasil analisis data pada siklus-2, hasil yang dicapai meliputi:

1) Aktivitas belajar siswa

Aktivitas belajar siswa pada siklus-2 berada tingkat tinggi, baik aktivitas belajar siswa pada tahap pendahuluan, maupun pada tahap belajar siswa pada penerapan yang meliputi; memahami materi, memperoleh informasi merumus hipotesis, dan membuat kesimpulan.

Aktivitas belajar siswa pada. pelajaran IPS Terpadu melalui model pembelajaran Numbered Head Together berada pada tingkat yang tinggi, dengan derajat Aktivitas sebesar 76,07, walaupun demikian perlu dioptimalkan lagi agar hasil belajar lebih meningkat. Ada beberapa faktor yang mendukung untuk meningkatkan hasil belajar antara lain:

a) Kecakapan guru memilih model dan metode mengajar

b) Siswa lebih aktif belajar sehingga hasil belajar meningkat.

c) Memberikan kesempatan lebih besar pada siswa untuk beraktivitas sedangkan guru sebagai pendamping saja.

2) Hasil belajar siswa

Hasil belajar siswa pada siklus - 2 terdapat 15 siswa yang memperoleh hasil belajar diatas penguasaan minimal dan 13 siswa yang memperoleh hasil belajar sesuai dengan yang diharapkan. Hasil belajar siswa pada pembelajaran IPS Terpadu melalui model pembelajaran Numbered Head Together sudah ada peningkatan, bahkan diatas penguasaan 
minimal. Faktor pendukung atas hasil yang diperoleh siswa adalah semangat dan aktivitasnya sangat tinggi oleh karena itu perlu diusahakan lagi agar aktivitas belajar siswa selalu diberi motivasi dengan menggunakan berbagai model pembelajaran dan metode yang bervariasi.

3) Tanggapan siswa

Pada siklus-2 ini siswa memberikan respon dan belajar melalui model pembelajaran Numbered Head Together pada IPS Terpadu sebagai berikut:

a) Dengan memiliki nilai-nilai Pancasila melalui berbagai buku sumber.

b) Dengan cara kelompok, kita saling bersaing untuk mendapatkan hasil yang lebih baik.

c) Kalau bias bapak/ibu guru mengajar menggunakan cara model pembelajaran Numbered Head Together pada semua pelajaran.

Hasil wawancara dengan siswa, dapat dikatakan semua siswa memberikan respon/tanggapan positif terhadap pembelajaran IPS Terpadu melalui model pembelajaran Numbered Head Together. Adapun factor pendukung terhadap hasil belajar siswa adalah positif yaitu: 1) siswa merasa diberikan kepercayaan kepada guru, 2) Metode dan alat peraga sesuai dengan materi. 3) suasana belajar menyenangkan, 4) siswa dapat menyelesaikan tugas kelompok atau tugas perorangan.

Beberapa tanggapan guru kelas sebagai berikut

a) Melalui model pembelajaran Numbered Head Together memang lebih baik, sebab memberikan kesempatan kepada siswa untuk berkreativitas.

b) Dalam kerja kelompok siswa saling berlomba, ada keinginan siswa untuk memperoleh hasil belajar lebih baik.

Hasil wawancara dengan guru kelas, setelah melihat hasil tindakan dalam penelitian ini cukup baik, maka guru kelas memberikan tanggapannya sebagai berikut: 1) Aktivitas belajar siswa cukup baik. 2) siswa mudah memahami materi pelajaran, 3) perlu dicontoh cara mengajar dengan menggunakan model belajar siswa aktif, 4) dengan alat peraga yang digunakan menunjang tercapainya Tujuan Pembelajaran yang ditetapkan..

Berdasarkan hasil Penelitian Tindakan Kelas diatas prosentasi ketercapaian pada siklus pertama mengalami peningkatan yang signifikan pada siklus kedua, maka dapat disimpulkan bahwa melalui model pembelajaran Numbered Head Together dapat meningkatkan kemampuan Memahami usaha persiapan kemerdekaan dalam mata pelajaran IPS Terpadu pada 
siswa Kelas IX.5 SMP Negeri 2 Metro

Tahun 2013.

\section{KESIMPULAN}

Berdasarkan hasil penelitian tindakan kelas ini, dapat disimpulkan bahwa Salah satu upaya untuk meningkatkan keberhasilan belajar siswa, yaitu dengan menggunakan pembelajaran aktif di mana siswa melakukan sebagian besar pekerjaan yang harus dilakukan. Siswa menggunakan otak untuk melakukan pekerjaannya, mengeluarkan gagasan, memecahkan masalah dan dapat menerapkan apa yang mereka pelajari. Belajar aktif merupakan langkah cepat, menyenangkan, mendukung dan menarik hati dalam belajar untuk mempelajari sesuatu dengan baik. Berdasarkan temuan hasil penelitian ini dapat disimpulkan bahwa model pembelajaran Numbered Head Together dapat meningkatkan kemampuan siswa memecahkan

Memecahkanmasalahyangberkaitan

denganMemahami usaha persiapan kemerdekaan dalam pelajaran IPS Terpadu siswa Kelas IX.5 SMP Negeri 2 Metro tahun 2013.

Adapun saran dalam penelitian ini adalah sebagai berikut:

1. Pembelajaran IPS Terpadu pada khususnya dapat menggunakan model pembelajaran Numbered Head Together sebagai salah satu alternatif dalam proses penyampaian pembelajaran di Sekolah.

2. Melalui pembelajaran model pembelajaran Numbered Head Together, guru dapat dengan mudah merespon potensi atau modalitas siswa dalam setiap kelompok belajar, apakah tergolong kepada kelompok Visual, atau kelompok Auditorial atau kelompok Kinestetik. Dengan demikian seorang guru yang profesional dapat lebih efektif dapat melakukan kegiatan proses pembelajaran, serta dengan mudah dapat merespon perbedaan-perbedaan potensi yang dimiliki peserta didiknya

\section{DAFTAR PUSTAKA}

Agus, Suprijono. 2013. Cooperative LearningTeori dan Aplikasi PAIKEM Yogyakarta: Pustaka Pelajar

Aidin Adlan, 2011. Penelitian Tindakan Kelas.Kudus: Dita Kurnia

Ibrahim, M, dkk. 2000. Pembelajaran Kooperatif. Surabaya : University Press.

Kagan, S. (1993). Cooperative learning. San juan Capistrano, Kagan Cooperative Learning.

Muslimin. (2000). Pembelajaran Kooperatif. Surabaya: Unesa University Press.

Slameto. 2003. Belajar dan Faktor-Faktor yang Mempengaruhinya. Jakarta: Rineka Cipta. 
